\title{
Instructional Media Model Based on Mobile Technology to Enriching Teaching Material for Primary School Students in Indonesia Post-Learning in the Classrooms
}

\author{
Bahar $^{1}$, Soegiarto ${ }^{2}$ \\ \{bahararahman@gmail.com ${ }^{*}$, ttsoegiarto@gmail.com $\left.{ }^{2}\right\}$ \\ 1,2 STMIK Banjarbaru, Jl. Ahmad Yani K.M. 33,5 Loktabat - Banjarbaru \\ *bahararahman@gmail.com
}

\begin{abstract}
The unavailability of adequate time for elementary school teachers in Indonesia to deliver learning material in the classroom causes learning to be ineffective. Use of e-learning, e-module, and Compact Disk Interactive Learning Technology to help students learn independently outside the formal study time in class still has disadvantages. This paper proposes a learning media model that utilizes Smart Phone-based mobile technology to help teachers deliver subject matter outside of formal learning time. This media serves as a medium for enriching subject matter that is not completed delivered in the classroom. A database server is placed in the school, containing subject matter as well as practice questions provided by the teacher according to the prepared learning plan. There is a smart feature that functions to manage learning materials, practice questions, and distribute them to students' smart phones under the control of the teacher's mobile device. Students learn through their Smart Phone-based mobile devices.
\end{abstract}

Keywords: Enrichment of Teaching Materials, Learning Media Model, Mobile Technology, Student Competence

\section{Introduction}

In planning learning in school, time management in class is a complex and difficult task for teachers, even though on the surface it seems quite simple and practical. It often happens to teachers who are inexperienced, find themselves having to race to complete a variety of topics in the shortest time possible in order to convey the entire contents of the targeted learning. Unfortunately, what seems to them to be an efficient use of time often results in little in student learning, if any. This shows that effective use of time is as important as the amount of time spent on a topic [1].

In general, elementary schools in Indonesia provide education about 6 hours per day for 180 days every year. The total time available for teaching is basically determined. Of the 6 hours available, there must be time to teach various subjects, plus time for rest, sports (physical education), switching between class hours, announcements and so on. Therefore, there is a lot of lost time allocation. The time allocated and used for a specific task is closely related to student academic achievement. The findings by the researchers show that the classroom as a place where students spend most of their time engaging in academic activities 
is the class that should be a place for students to get academic achievement. However, it often happens that part of the school time is used for lunch, breaks, meetings, and other extracurricular activities which reduce the time for academic activities. This has an impact on the inaccuracy of delivery of teaching materials by teachers to students.

The methods of maximizing the usual time allocation include preventing late teaching and early termination, preventing disruption during the learning process, handling routine procedures smoothly and quickly, minimizing the time spent on developing student discipline, and using busy time effectively [1]. If the time for educational activities in the classroom still cannot be fulfilled, then another effort that can be done by the teacher is to extend the time through homework assignments. Other efforts commonly done by students are to take part in learning activities outside of formal learning time, such as tutoring in school outside of formal study time or in non-formal institutions, and to study independently with the support of the family environment. However, efforts to extend study time outside formal learning time are constrained by the family environment (economic factors and various other non-economic factors) that do not support the process of enriching teaching materials after learning in class [1].

Various studies have been conducted to create learning media in an effort to increase the effectiveness of students learning independently. Rosenberg in [2] introduced the concept of "cyber teaching", namely the teaching process carried out using the internet. Another term that is popular today is e-learning, which is a learning model using communication and information technology media, especially the internet, with the principle of e-pedagogy in the independent learning process [3]. E-learning with the concept of Distance Learning that is supported by the internet network can support the concept of learning anytime and anywhere, but has an impact on the aspects of information obtained. That is not guaranteed the accuracy of information from the internet so that it is very dangerous if students (especially elementary school students who immature) lacks a critical attitude to the information obtained.

Suarsana [4] introduced a problem-oriented e-module to improve students' thinking skills. The e-module guides students to look for problem solving independently, thus providing a concrete experience in problem solving. The e-module fosters and trains higher-order thinking skills including critical thinking skills. Learning to use modules greatly values individual differences, so students can learn according to their ability levels. However, learning by using modules has disadvantages such as: high material development costs and long development time, and requires high discipline of learning and motivation that students may not have in general and students who are not yet mature in particular.

Wulandari [5] developed an interactive Compact Disk (CD)-based learning media to provide a variety or variation of learning, especially for the independent learning process, so students are more interested and motivated to learn. Waskito [6] has also developed interactive CD-based learning media for elementary school mathematics lessons, which combine multimedia elements (text, sound, images, and video) in its development. Multimedia-based interactive learning CDs provide a variety or variety of learning, especially for independent learning processes, so students will be more interested and motivated in learning. However, to be able to run interactive learning CD-based applications requires hardware such as a Computer Central Processing Unit (CPU) and CD-R / RW, so it is not efficient to be used to study anytime and anywhere.

The development of Information and Communication Technology especially smartphone technology is currently growing rapidly. Many early childhood or elementary school students use smartphones as a medium to communicate with parents when outside the home. Smartphones are also favored by elementary school age children for entertainment, especially 
for playing (games). On the one hand children tend to use smartphones with game features (games) for a long time (at any time) so that it can interfere with learning activities because they prefer playing games rather than learning [7] [8], but on the other hand smartphone technology that carries the concept of practicality (mobile) can be used for a variety of academic activities that are of use value if managed intelligently, especially as an effective learning media for children. Supriyono, et al. [9] examined the use of Android-based mobile devices as a medium for learning Hadith Sciences. The mobile-based application that was built has two main features, namely features for independent learning and features for assessment (practice questions). This application is also equipped with a search facility for certain topics that you want to learn. Students can learn anytime and anywhere by utilizing this Android-based learning application. User test results show that this mobile technologybased application is practical and effective in studying Hadith. Puspa, Nugroho and Puspitarini [10] have examined the use of mobile technology-based learning media in learning systems independently. In this study Android-based game applications were made as a medium for early childhood learning. This application provides features for learning to read and recognize objects and features for writing or drawing, all of which are packaged in the form of interesting games. User test results show that this Android-based mobile application can develop thinking power and creativity, with an interface that is easy to understand and operate at an early age. Pahrudin [11] has also developed a Physics Summary Book based on smartphone applications, which can be used by students to learn and practice solving practice questions independently without being controlled by subject teachers. Posttest test results in the experimental class showed the Minimum completeness Criteria which reached $93.75 \%$, so it was concluded that the smartphone-based learning application is very feasible to use as an effective learning media.

This paper proposes a learning media model that utilizes mobile technology (smartphone) to help teachers deliver subject matter outside of formal learning time, as a form of enriching subject matter that is not completely delivered in the classroom due to time constraints. Subject material in the form of teaching materials and practice questions delivered to students, distributed in a controlled manner (gradually) through a global communication network to the smartphone device of students in accordance with the stages of learning contained in the learning design. Thus, the learning strategy offered in this mobile-based learning media technology is independent learning that is controlled by the teacher.

\section{Research Method}

This study uses the Research and Development Method (R\&D), adapting the stages of Research and Development proposed by [12]. The steps of the study consist of First, Analysis of system requirements involving learning designers, institutional management, and college graduates or the business world as graduate users [12]. They are included in the formulation of competencies in the field of software modeling needed in learning design. Second: Development of learning design, following the procedure for developing learning designs proposed by [13]. The development stage consists of two main steps, namely identifying learning needs and developing learning designs. The advanced PBL concept is implemented at the scene of preparing the learning strategy. Third: Formative Evaluation to test the effectiveness of the model. 
Formative Evaluation, consisting of (1) product expert validation (learning aspects and aspects of learning material), and (2) Product of Mobile Technology Application trials (Individual learners and small groups). At the end of each trial phase, data analysis and product revisions are carried out based on the input obtained from the experiment.

\section{The Proposed Model Concepts}

Learning strategies carry the concept of mixed learning (blended learning). At the beginning of the process, students and teachers conduct face-to-face learning in class according to the schedule set by academic management in the school. Teaching materials that are not finished are delivered in class, distributed to students through learning media based on mobile technology systems. Students study learning material and practice working on practice questions through a smartphone device at certain times, under the control of the subject teacher outside formal study hours. The architecture of learning media based on mobile technology systems is presented in Figure 1.

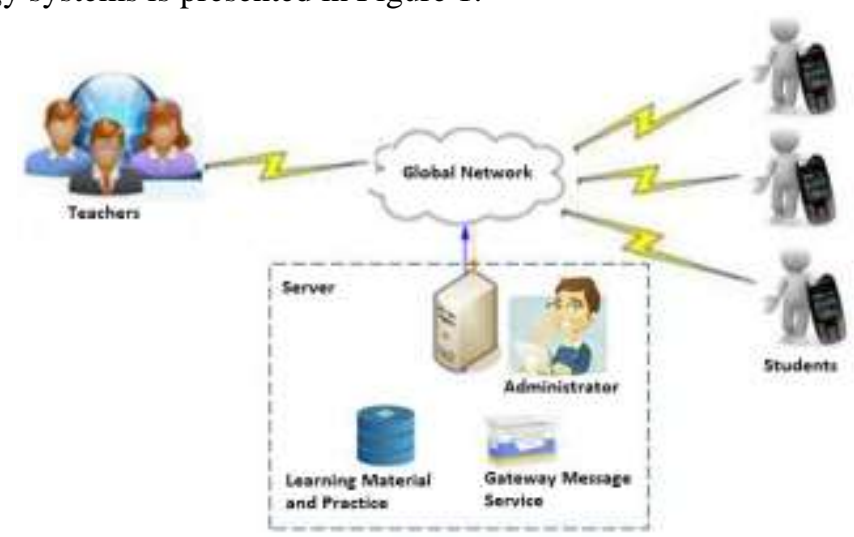

Fig.1. Architecture of Learning Media Based on Mobile Technology Systems

In Figure 1, a computer server containing a database of subject matter and practice questions sourced from the subject teacher is placed in the school. The server is managed by a System Administrator. Study materials and practice questions are regularly distributed to students' smartphones via the internet. The distribution of teaching materials and practice questions is controlled by the subject teacher through the smartphone terminal, in accordance with the learning design that has been prepared.

The application interface of a mobile technology-based application is divided into three main modules, namely: the interface module on the system administrator side (figure 2), the interface module for subject teachers (picture 3), and the interface module for students (picture 4).

The operation of the system is divided into 3 main stages, namely the stage of user registration by and classes conducted by the System Administrator, the stages of learning preparation conducted by the teacher, and the stages of learning conducted by students. In the initial stages (user and class registration), the system administrator registers all study participants and instructors into the system to get an authentication account (figure 2). At the beginning of each semester, the system administrator also makes class plans, by registering and giving a unique identity to each subject and sub-subjects to be taught in all classes, 
including assigning study participants and instructors to each class that is formed, so that each eye class lessons and subtopics at each grade level have a unique identity.

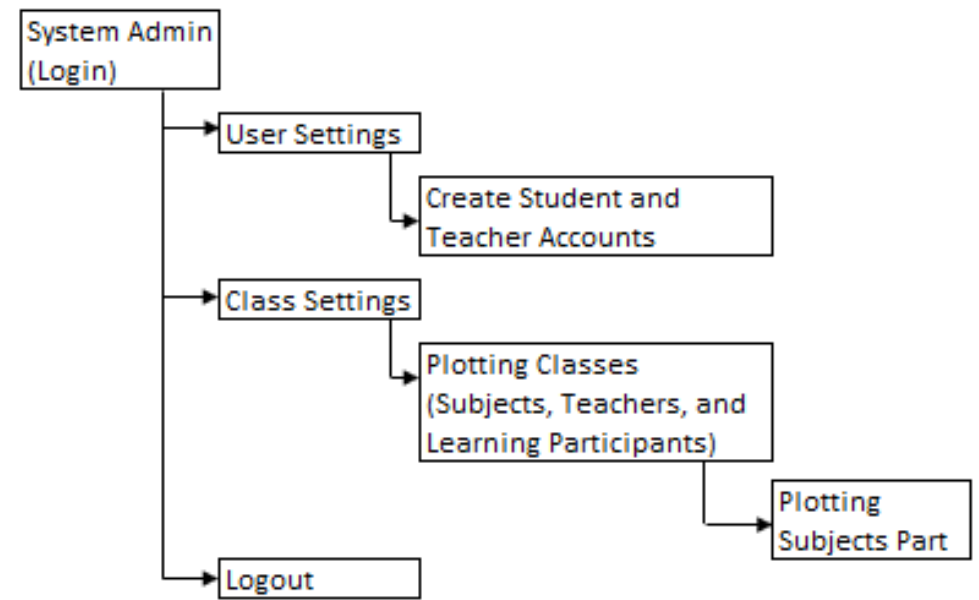

Fig.2. Site Map Interface on the System Administrator Side

In the second stage (the preparation phase of learning), the subject teacher uploads the main teaching materials and enrichment teaching materials in the form of text files or multimedia-based tutorial files, as well as practice questions for each class that is formed (figure 3). Furthermore, subject teachers periodically distribute teaching materials along with practice questions through a global communication network to students in accordance with the planned learning schedule. The distribution of teaching materials and practice questions can be done simultaneously to all participants studying in a particular class, or for some reason only addressed to certain students who are wanted. With concepts like this, the teacher still holds a central role in controlling the learning process. In this module the teacher can also see the results of learning feedback (student test results) for each sub subject that students have studied, both overall student test results and for certain students, to be a reference for teachers in evaluating the learning system that is held. 


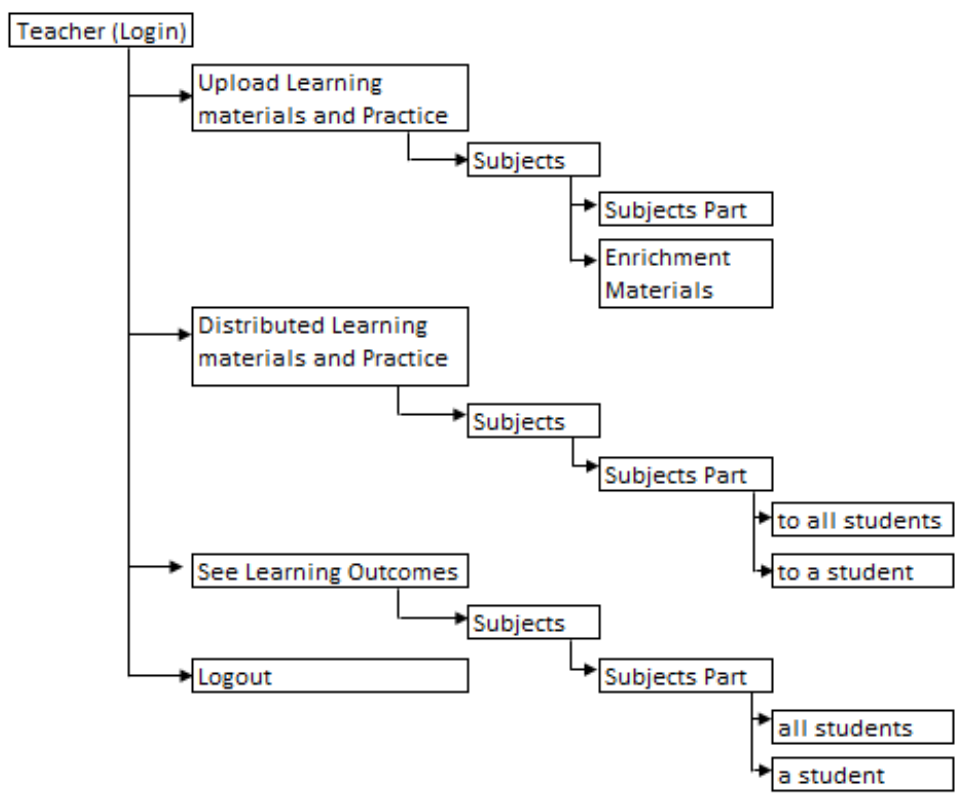

Fig.3. Site Map Interface on the Teacher's Side

The third stage is the core stages of a learning system based on mobile technology, namely the stages of independent learning carried out by students through a smartphone device. Each teaching material and practice questions distributed by subject teachers in a particular class will be known by students through the "New Learning" menu interface (figure 4). Students access new learning files, study them independently, and practice answering practice questions at the end of each learning session. Students can see the interim results obtained in the practice process (answering practice questions), and are given the opportunity several times to restart studying certain sub topics (remedial) if the test scores have not yet reached the mastery standards set by the subject teacher, through the interface "Learning and Remedial History" menu. Students also have the opportunity to learn enrichment teaching materials to further deepen mastery of the material in certain subsubjects before following the remedial process. 


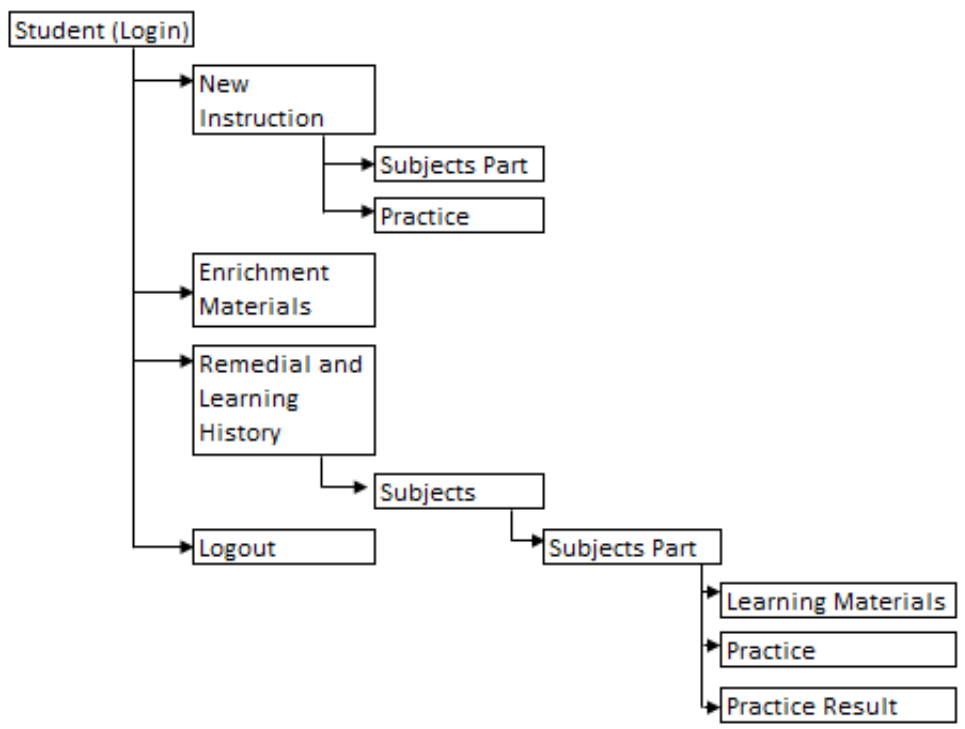

Fig.4. Site Map Interface on Student Side

This research was carried out from January to October 2019, with a total of 100 samples. We divided the data into two groups consisting of 'no CP' (50 data without $\mathrm{CP}$ ) and 'with $\mathrm{CP}^{‘}(50$ data with $\mathrm{CP}$ intervention).

\section{Results and Discussion}

After the draft instructional media product has been developed, the next step is the assessment process by experts (media experts and learning design experts). Inputs provided by experts are used as references to make improvements to learning media product.

The expert assessment was carried out using a questionnaire adapted from 'Evaluation and Selection of Learning Resources: A Guide 2008'. The assessment range was 1-4 with an interpretation of $4=$ appropriate, $3=$ sufficiently appropriate, $2=$ inaccurate, and $1=$ inappropriate. Each value given is transformed into a percentage with a description of the value $85-100=$ very feasible does not need to be revised, $75-84=$ feasible does not need to be revised, $55-74=$ inadequate need to be revised, and $0-54=$ not feasible need revision. In the questionnaire, expert can provide suggestions, criticisms, and input on the learning media product developed. The following is presented results of expert evaluations of the instructional media product developed Table 1 .

Table 1. Results of Expert Validation

\begin{tabular}{l|l}
\hline Expert & Score \\
\hline Media Expert & $82.1 \%$ \\
Instructional Design Expert & $83.5 \%$ \\
Average & $82.8 \%$ \\
\hline
\end{tabular}

Based on the table 1, it can be explained as follows: 
1. The results of the media expert's assessment obtained a value of $82.1 \%$, indicating that the instructional media product developed were in the category of proper use.

2. The assessment of Instructional design experts on instructional media product obtained a value of $83.5 \%$, in the category worthy of use.

3. Overall the average value of the instructional media product validation developed is 82 , $8 \%$. This value is in the category worthy of use.

Results of the validation in table 1, showing that instructional media product based on mobile technology are very suitable to be used as instructional resources. The instructional media product validation percentage result has not reached $100 \%$ because there are still shortcomings of the product, such as the lack of images, animation and videos that support the material. The following is expert advice as a reference for improving the instructional media product. After validation and revision based on expert input, the instructional media product was tested on students. The trial process consists of two stages: Individual learners and small groups. Individual trials were conducted involving 3 students and a large group trial involved 9 students. The students were selected randomly, where there were students who had high learning outcomes, students who had moderate learning outcomes, and students who had low learning outcomes. After being believed to be heterogeneous, students were asked to provide responses, suggestions and input by filling out the feasibility questionnaire given previously. The last results of student responses (large group trial) to the instructional media product after obtaining suggestions and input at the individual learner trial can be seen in table 2.

Table 2. Results of Student Responses

\begin{tabular}{l|l}
\hline Aspect & Results \\
\hline Attractive Display & $80.7 \%$ \\
User Friendly & $80.1 \%$ \\
Material Presentation & 82.9 \\
Average & $81.2 \%$ \\
\hline
\end{tabular}

There are two aspects of assessment conducted by students on instructional media products, namely non-functional aspects (attractive display and user friendly) and functional aspects (material presentation). In the non-functional aspect (physical appearance), students assess that the instructional media product developed has an attractive appearance (the assessment results reach $80.7 \%$ ) and easy to use (the assessment results reach $80.1 \%$ ). In the functional aspects instructional media products based on mobile technology developed can present teaching materials effectively (can be used by students to learn anytime and anywhere, and can present learning materials that are easily understood by students), with an assessment result reaching $82.9 \%$. These results are in line with the findings of [9] who suggested that practical and effective mobile technology-based learning applications are used in learning, and the findings of [14] which recommends the use of smartphone applications as an effective learning aid, and can be used as a complement to traditional learning. The findings in this study are also in line with the findings of [15] who developed an Android smartphone-based learning media, and found that learning media based on mobile technology was appropriate to be used as a learning resource for students.

\section{Conclusions}


The results of student responses at the large group trial shows that the instructional media product based on mobile technology is very feasible to use as an instructional resource to enriching teaching material for Primary School Student post-learning in the classrooms. The result obtained an average value of $81.2 \%$

The limitation of this research is that in the product evaluation process there has not been a study involving teacher perceptions as an inseparable part in the mobile technology-based learning system in elementary schools.

\section{Acknowledgments}

Thank you to the Director of Research and Community Service - Indonesian Ministry of Research, Technology and Higher Education for funding this research, in the 2019

Competitive Research Grant (Basic Research) scheme.




\section{References}

[1] Liez, I. Perencanaan waktu dan Ruang [Online].Available : http://iliyaliez.blogspot.co.id/2011/11/perencanaan-waktu-dan-ruang.html. (2017).

[2] Kwartolo, "Teknologi Informasi dan Komunikasi dalam Proses Pembelajaran", Jurnal Pendidikan Penabur, Vol. 9, No. 14, pp.15-43. (2010).

[3] Wijaya, M, "Pengembangan Model Pembelajaran e-Learning Berbasis Web dengan Prinsip e-Pedagogy dalam Meningkatkan Hasil Belajar", Jurnal Pendidikan Penabur, Vol. 11, No. 19, pp. 20-37. (2012).

[4] Suarsana, I. M., Mahayukti, G.A, "Pengembangan E-Modul Berorientasi Pemecahan Masalah Untuk Meningkatkan Keterampilan Berpikir Kritis”, Jurnal Pendidikan Indonesia, Vol. 2, No. 2, pp. 264-274. (2013).

[5] Wulandari, F.R.A., Dewi, N.R., and Akhlis I, "Pengembangan CD Interaktif Pembelajaran IPA Terpadu Tema Energi Dalam Kehidupan Untuk Siswa SMP”, USEJ, Vol. 2, No. 2, pp. 262-268. (2013).

[6] Waskito, D, "Media Pembelajaran Interaktif Matematika Bagi Sekolah Dasar Kelas 6 Berbasis Multimedia”, Journal SPEED, Vol. 11, No. 3, pp. 59-65. (2014).

[7] Rozalia, M. F, "Hubungan Intensitas Pemanfaatan Gadget Dengan Prestasi Belajar Siswa Kelas V Sekolah Dasar”, Jurnal Pemikiran dan Pengembangan SD, Vol. 5, No. 2, pp. 722-731. (2017).

[8] Tatminingsih, S, “The Impact of ICT Use on Early-Age Children Behavior: A Case Study Of 4-7 Years Old”, Jurnal Pendidikan, Vol. 18, No. 1, pp. 42-52. (2017).

[9] Supriyono, H., Saputra, A.N., Sudarmilah, E., and Darsono, R, "Rancang Bangun Aplikasi Pembelajaran Hadis Untuk Perangkat Mobile Berbasis Android”, Jurnal Informatika, Vol. 8, No. 2, pp. 907-920. (2014).

[10] Puspa, D. W., Nugroho, A.P., dan Puspitarini, E.W, "Game Edukasi Berbasis Android Sebagai Media Pembelajaran Untuk Anak Usia Dini”, Jurnal Informatika Merdeka Pasuruan (JIMP), Vol. 1, No. 1, pp. 46-58. (2016).

[11] Fahrudin, A, "Development of Physics Summary Book as a Smartphone-Based Application and Its Effect on Elasticity Learning Achievement", Physics Education Journal, Vol. 1, No. 1, pp. 22-33. (2018).

[12] Gall, M. D., Gall, J. P., Borg, W. R, Applying Educational Research, Seventh Edition, USA: Pearson . (2015).

[13] Dick, W., Carey, L., Carey, J.O, The Systematic Design of Instruction, Eight Edition, USA: Pearson. (2015).

[14] Kim, S.-J., Shin, H., Lee, J. E., Kang, S., \& Bartlett, R, “A smartphone application to educate undergraduate nursing students about providing care for infant airway obstruction”, Nurse Education Today, Vol. 48, pp. 145-152. (2017).

[15] Amirullah, G., Susilo, "Pengembangan Media Pembelajaran Interaktif pada Konsep Monera Berbasis Smartphone Android”, Wacana Akademika, Vol. 2, No. 1, pp. 3847. (2018). 